\title{
LATAR BELAKANG KESENIMANAN DAN KARYA-KARYA M. RASYID
}

\author{
Oleh: \\ Treny hera \\ (Dosen FKIP Program Studi Pendidikan Sendratasik Universitas PGRI Palembang)
}

\begin{abstract}
Abstrak
Rasyid adalah koreografer di Kabupaten Muara Enim Sumatera Selatan, keinginan akan hal-hal yang indah merupakan hasrat hidup yang pemenuhannya menunggu sampai hasratnya terpenuhi, memberikan ruang untuk selalu berpikir untuk selalu menciptakan hal baru, berimajinasi hingga terbentuk konsep garapan baru, dan mengapresiasikan semua yang ada di dalam kepala menjadi sebuah ide baru dan ide kreatif dalam berkarya. Rasyid adalah seseorang yang menyukai hal-hal yang baru tetapi ia juga sangat menghargai dan menjaga tradisi yang telah ada. Rasyid beranggapan masa depan dan masa kini berawal dari masa lalu, ide kreatif, imajinasi ia dapatkan dari tradisi yang telah ada kemudian dijadikan sesuatu yang baru agar tradisi tetap diminati oleh masyarakat banyak dalam kemasan yang lebih menarik. Seorang koreografer yang handal adalah jika ia memiliki motivasi yang tinggi dalam menciptakan karya dan menghasilkan sebuah entitas yang unik, kaya, menarik dan dapat memberikan rangsangan-rangsangan kepada penikmat agar ikut berimajinasi dan sajian karya dalam kemasan yang menarik.

Kata Kunci: Seni, Seniman.
\end{abstract}

\section{A. PENDAHULUAN}

Rasyid adalah seniman di Kabuapten Muara Enim. Seniman adalah para pelaku seni, siapa saja yang melakukan pekerjaan atau praktisi dalam ranah kesenian. Profesi kesehariannya sebagai pengawas tingkat Sekolah dasar dan Sekolah Menengah Pertama di Kabupaten Muara Enim. Sehingga tak heran jika karyanya bersifat mendidik. Sebagai seniman, Rasyid selalu berkarya mengangkat fenomena keseharian yang terjadi di daerah setempat, ia selalu menyempatkan dirinya untuk melihat pertunjukan dan pameran, dan Rasyid dipercaya oleh pemerintah setempat untuk mewakili Muara Enim ketika ada kegiatan seni di luar kabupaten. 


\section{B. METODE PENELITIAN}

Metode penelitian yang digunakan yakni deskriptif kualitatif, sehingga akan di deskripsikan sesuai dengan hasil analisis data yang telah tersaring yang didapat di lokasi penelitian. Metode deskriptif adalah suatu metode dalam pencarian fakta status kelompok manusia, suatu objek, suatu kondisi, suatu sistem pemikiran ataupun suatu peristiwa pada masa sekarang dengan interprestasi yang tepat (Sudarmayanti, dkk., 2002:33).

Metode kualitatif digunakan dalam penelitian Latar Belakang Kesenimanan dan Karya-Karya M. Rasyid. Secara tehnik pengumpulan data berupa data observasi, wawancara dengan pelaku seni dan masyarkat pendukung kesenian tersebut, dan menggunkan pengumpulan data studi pustaka melalui buku catatan pribadi nara sumber dan riwayat karya-karyanya melalui dokumentasi pribadi, maupun dokumentasi yang diperoleh dari Dinas Kebudyaan setempat.

\section{C.PEMBAHASAN}

\section{a) Latar Belakang Pendidikan}

\section{Pendidikan Formal}

Muhamad Rasyid Abdul Rahim dengan panggilan Rasyid lahir pada tanggal 6 April 1954 di suatu desa kecil Nanjungan Gedung Agung Kecamatan Merapi Kabupaten Lahat, namun ia besar di Kabupaten Muara Enim karena sejak SMP ia melanjutkan sekolahnya di Kabupaten Muara Enim. Sebagai anak yang hidup diperantauan, ia tetap patuh pada pesan sang ayah, agar terus belajar dan berkarya dimanapun kita berada. Pengalaman ia tinggal di kota, jauh dari orang tua, ia dititipkan pada keluarga Majenang teman ayahnya. Pada saat inilah Rasyid mulai mengenal kebudayaan dan kesenian Kabupaten Muara Enim.

Rasyid merupakan buah kasih Abdul Rahim dan Siti Adenah, Rasyid adalah anak kedua dari empat bersaudara. Satu kakak laki-laki, satu adik laki-laki dan satu adik perempuan. Hidup dimasyarakat etnik kikim yaitu penduduk asli Kabupaten Lahat Muara Enim. Kedua orang tuanya adalah seorang petani. Kegemaran ia terhadap dunia seni sama sekali tidak dimiliki oleh kedua orang tuanya (wawancara Rasyid, Maret 2014).

Cara hidup keluarga dan cara mendidik yang dilakukan orang tuanya menekanakan pada anaknya agar hidup rukun dan menjaga dengan baik kebudayaan dan 
adat istiadat setempat, yaitu saling menghormati sesama masyarakat. Rukun antar umat beragama dan menjaga rasa saling menghargai sesama. Keluarga ini hidup dalam satu lingkungan mayoritas agama Islam, hal ini mempengaruhi bagaimana tata cara bersosialisasi dalam kehidupan sehari-hari. Yaitu menganut kultur permisif, mudah bergaul dan mudah akrab dengan siapa pun. Hal ini menjadikan hubungannya sesama masyarakat setempat terjalin dengan baik.

Awal pendidikan sekolah dasar di SD Negeri Gedung Agung dan tamat pada tahun 1966. Rasyid melanjutkan sekolah menengah pertama (SMP) di Kabupaten Muara Enim, tahun 1972 ia menyelesaikan Sekolah Pendidikan Guru (SPG) di Kabupaten Muara Enim, dan melanjutkan Diploma II pendidikan guru sekolah dasar (PGSD) tahun 1996 hingga akhirnya Strata 1 PGSD pada tahun 2005.

Kegemaran ia melukis dan bernyanyi terus berkembang dimulai keikutsertaannya pada festival bernyanyi utusan sekolah dan mendapat juara II. Masa remajanya penuh keinginan dan hayalan karena keadaan ekonomi yang serba kekurangan. Keadaan orang tuanya pada waktu itu tidak menghentikan cita-citanya untuk terus belajar menjadi seorang yang ahli dibidang seni, selain bernyanyi dan melukis, ia pun aktif dalam kegiatan olah raga seperti olah raga basket dan lari.

Tahun 1972 orang tua Rasyid pindah dan menetap di Kabupaten Muara Enim. Tahun 1974 adalah awal karir Rasyid menjadi seorang guru SD Negeri Tanjung Baru Kecamatan Pendopo, selama kurang lebih dua tahun enam bulan ia tugas di sekolah ini yang posisinya sangat jauh dari kediamannya, tetapi ia sangat mencintai profesi ini. Berbagai penataran dan pelatihan selalu diikuti olehnya, ketekunan ia sebagai seorang guru menjadikan ia sebagai guru yang berprestasi dan hingga akhirnya menemukan tambatan hatinya. Tepat tanggal 25 Septembe 1977, Rasyid menikah dengan Nuraini, gadis buah hati pasangan Purnawirawan dan Hadifah, ia mendapat seorang istri yang dilahirkan di Kabupaten Musi Banyu Asin. Seminggu setelah resepsi pernikahan ia dan istri kembali menetap di Pendopo desa tempat Rasyid mengajar. Disini kedatangan mereka disambut dengan acara selamatan. Bulan Juli 1978 SK mengajar Rasyid keluar, dan oktober 1978 ia pindah mengajar di SD Negeri Kuta Dewa dan istrinya pun adalah seorang guru yang mengajar di Kuta Dewa tempat yang sama. 


\section{Pendidikan Non Formal}

Pendidikan non formal dilakukan Rsyid melalui kegiatan penataran atau pelatihan dan lewat sanggar-sanggar tari. Penyelenggaraan penataran atau pelatihan tari diikuti Rasyid yang melibatkan para pembina seni yang materinya adalah perkembangan seni dan cara menggagas konsep garapan tari di Sumatera Selatan. Pada waktu itu penataran diikuti oleh para pembina seni yang merupakan perwakilan dari daerah-daerah se wilayah Sumatera Selatan. Hasil penataran atau pelatihan yang telah Rasyid ikuti kemudian ia sebarkan ke daerahnya, khususnya Kabupaten Muara Enim.

Juli 1980 Rasyid pindah ke Muara Enim. Hingga akhirnya ia menjadi Kepala Sekokah Negeri 17. Seperti yang dikemukakan Rasyid, dalam kariernya sebagai pekerja seni berjalan dengan baik, meski sering mendapat tantangan. Tahun 1985 Rasyid ikut serta Duta Seni Sumatera Selatan Pekan Seni Sesumatera di Banda Aceh. Rasyid juga pernah mengikuti pendidikan di Padepokan Seni Bagong Kusumodiarjo di Yogyakarta (1986). Pada kesempatan ini ia terpilih sebagai ketua dewan kesenian selama enam bulan dan diakui pendidikannya dan terpilih sebagai cantrik teladan.

Semasa kecil Rasyid gemar menirukan gerak tari yang ia lihat dari Sanggar tari di Muara Enim, sepulang dari mengaji ia melintasi sanggar tari di Muara Enim untuk melihat dari luar kegiatan sanggar tersebut, secara diam-diam ia sering ikut menari dari luar, pengalam ia dimasa kecil ini sangat berharga tuturnya. Latar belakang orang tuanya sebagai seorang petani, ia sering diajak ibunya untuk beraktivitas disawah, pada masa itu untuk memproses padi menggunakan alat penggiling tradisional yaitu isaran. Rasyid kerap kali naik di atas isaran dan menari karena asik mengikuti perputaran gilingin padi tersebut. Berdasarkan apa yang dikemukakan Rasyid, dari kegiatan ibunya sebagai petani ia bisa menirukan gerakan alam dalam bentuk gerak tari. la banyak belajar dari aktivitas seharihari yang terjadi di sawah dan mengekspresikan apa yang ia lihat dalam bnetuk karya tari.

Menjadi seorang koreografer menurutnya sudah menjadi bagian dari kehidupan sehari-harinya, keinginan akan hal-hal yang indah merupakan hasrat hidup manusia yang pemenuhannya menunggu sampai hasratnya terpenuhi, memberikan ruang untuk selalu berpikir untuk selalu menciptakan hal baru, berimajinasi hingga terbentuk konsep garapan baru, dan mengapresiasikan semua yang ada di dalam kepala menjadi sebuah ide baru dan ide kreatif dalam berkarya. Rasyid adalah seseorang yang menyukai hal-hal yang baru 
tetapi ia juga sangat menghargai dan menjaga tradisi yang telah ada. la beranggapan masa depan dan masa kini berawal dari masa lalu, ide kreatif, imajinasi ia dapatkan dari tradisi yang telah ada kemudian dijadikan sesuatu yang baru agar tradisi tetap diminati oleh masyarakat banyak dalam kemasan yang lebih menarik.

Seorang koreografer yang handal adalah jika ia memiliki motivasi yang tinggi dalam menciptakan karya dan menghasilkan sebuah entitas yang unik, kaya, menarik dan dapat memberikan rangsangan-rangsangan kepada penikmat agar ikut berimajinasi dan sajian karya dalam kemasan yang menarik (wawancara Rasyid, Maret 2014). Seorang koreografer merupakan seorang seniman yang kreator dan komunikator, artinya selain kreatif seniman juga harus bisa menjadi jembatan antara penikmat seni dan pengkaryanya. Karena tidak semua masyarakat penikmat seni mampu menelaah, dan menerima, bahkan menikmatinya. Menurut Lois Ellfeldt (1977:12) :

Koreografi adalah pemilihan dan tindakan atau proses pemilihan dan pembentukan gerak menjadi sebuah tarian. Asal katanya berasal dari bahasa Yunani, choreia (tariian koor) dan graphia (penulisan). Secara harfiah koreografi berarti merencanakan laku, baik ditulis maupun tidak. Sekalipun demikian oleh karena tari adalah bahasa, koreografi berarti memperhatikan pengaturan bahasa menjadi suatu bentuk.

Pengetahuan yang luas tentang seni, terutama daerah setempat dan dengan ketekunan yang Rasyid miliki, menjadikan ia sebagai seorang koreografer laki-laki yang aktif dan kreatif dalam berkarya. Karya-karya Rasyid memeliki keanekaragaman tema, ia menyalurkan keinginannya dalam menyusun suatu karya. Misalnya dalam setiap karya Rasyid memiliki tema yang berbeda satu sama lain dan adala pula bperkembangan dari tema yang telah ada, tetapi secara ide garapan dan bentuk tarinya berbeda.

Salah satu karya Rasyid, tari Kinjau Ibungan yang kemudian dari judul dan tema tersebut kemnudian berkembang lagi menjadi sebuah karya tari yang berjudul Kinjau Betuah. Tari yang berkisah kehidupan sehari-hari perempuan-perempuan di Kabupaten Muara Enim sebagai petani, dengan bentuk garap dan sajian yang berbeda.

Tema yang telah diangkat dalam karya-karya Rasyid terinspirasi dari pengalam pribadi, cerita legenda masyarakat setempat, kisah nyata yang terjadi dalam kehidupan sehari-hari, bahkan pengalaman pribadi seseorang yang diamatinya dan menarik untuk diangkat menjadi sebuah karya baru. Tak dapat dipungkiri seorang koreografer adalah laku 
kreatif, dan sebagaimana laku kreatif seringkali menjadi sesuatu yang unik dan menarik.

Rasyid adalah penari dan koreografer yang memiliki kedisiplinan yang tinggi dalam menekuni profesinya. Dalam kegiatan sehari-haripun ia sangat disiplin dan menghargai waktu. Kegiatannya terstruktur mulai dari bangun tidur samapi dengan tidur lagi, setiap harinya ia sangat memanfaatkan waktu yang ada, bahkan kegiatannya selalu direncanakan dalam bentuk jadwal harian yang ditulis dalam papan kegiatan dirumahnya.

Sikap disiplin waktu dalam berkesenian telah direncanakannya dengan tujuan agar hasilnya maksimal dan dapat terprogram dengan baik. Misalnya ada job yang telah dijadwalkan bulan depan, ia persiapkan setengah bulan lebih awal untuk melakukan proses latihan dan persiapan kostum, dan unsur pendukung lainnya. la juga menulis kegiatan-kegiatan ia dalam buku agenda, dan masa kecilnya hingga menikah dituliskannya dalam sebuah buku sebagai arsip pribadi, hal ini dilakukannya agar sesuatu yang telah terjadi dapat dikenang dengan membaca buku tersebut, bahkan pengajuan proposal kepada pemerintah setempat pun masih disimpannya dengan rapi, hal ini dilakukannya sebagai acuan untuk melakukan sesuatu dimasa yang akan datang. Kedisplinan ini dimilikinya samppai dengan saat ini.

Karya-karya Rasyid berorientasi pada pengembangan bentuk-bentuk tari yang berkembang di Sumatera Selatan dan Kota Jakarta, salah satu bentuk ragam gerak hormat dalam tari Sembah Rasyid mengambil motif orang Jakarta ketika mengucapkan salam sesama manusia dan sedikit banyak karya-karya Rasyid menggunakan gerak-gerak tari Sumatera Selatan yang telah memiliki perkembangan. Sebuah bekal yang menjadi acuannya dalam berkarya, adat istiadat, dan teknik-teknik tari di Sumatera Selatan telah dikuasai dan melekat pada dirinya berdasarkan pengalaman berkesenian. Hal iin merupakan latar belakang yang mendominasi pada tiap karya-karya tari Rasyid.

Rasyid tidak hanya memikirkan masalah yang berhubungan dengan tarian yang telah diciptanya, ia juga memikirkan tentang kelangsungan kehidupan dan eksistensi karyanya dimata masyarakat setempat dan Pariwisata. Untuk merealisasikan kekhawatiran ini, Rasyid selalu mencari peluang untuk mementaskan karya-karyanya dalam tiap event di Kabupaten Muara Enim dan di luar kabupaten. Mulai dari pentas festival, lomba-lomba seni tari, dan kegiatan seni lainnya guna menjaga eksistensi karya-karyanya dan menunjang kelangsungan profesinya sebagai koreografer. 
Karya-karya Rasyid merupakan hasil eksplorasinya Rasyid peroleh dari pencarian ide-ide, pengalaman pribadi dalam berkesenian, buku-buku dan sumber data yang didapat dalam lingkungan kehidupan sehari-hari masyarakat setempat khususnya. Karya-karya Rasyid yang pernah disajikan mampu memberikan tontonan, nilai moral, nilai sosial, makna-makna yang terkandung dalam setiap bentuk sajian yang dipentaskan.

\section{b) Kegiatan Rasyid sebagai koreografer}

Rasyid sebagai penari dan koreografer memiliki semangat dan keinginan yang kuat untuk menghasilkan karya-karya yang baru, dan mengikuti perkembangan zaman serta tak kala penting adalah kebutuhan masyarakat.

Rasyid mulai menciptakan karya tari pada tahun 1985 dengan tari Ngibing sebagai karya pertamanya. Jenis kegiatan sebagai duta seni Aceh, Jakarta pada tahun 1985 menambah pengalamannya dalam berkesenian dan memperkaya ide-ide baru nantinya. Utusan pemuda Muara Enim sebagai Catrik Teladan Angkatan XVI di Padepokan Seni Bagong pada tahun 1986 di Yogyakarta. Tahun yang sama Rasyid sebagai penari PSBK pementasan di Jawa Timur-Bali.

Rasyid sebagai koreografer pada tahun 1987, ia menggarap tari masal MTQ XVI SUMSEL di Muar Enim dan festival teater SUMSEL di Kota Lubuk Linggau dan Kota Palembang tahun 1988 sebagai aktor terbaik II, sutradara terbaik II, dan pemeran terbaik

III. Pengabdiannya kepada masyarakat dan prestasi yang telah ia raih tak lepas dari kedisplinan dan ketekunan ia dalam mencintai profesinya ini.

Selain pengalaman sebagai aktor, koreografer tari dan teater, Rasyid juga memiliki pengalaman yang sangat berharga ketika ia sebagai penembang lagu daerah menyambut Presiden Soeharto di PTBA Tanjung Enim.

Tahun 1990 Rasyid mendirikan sanggar tari Arizka Cipta hingga sekarang keberadaan sanggar tari ini sangat eksis di Kabupaten Muara Enim khususnya, tak jarang sanggar pimpinan Rasyid sebagai pengisi acara pernikahan setiap minggunya di gedung Kesenian dan gedung Putri Dayang Rindu Kabupaten Muara Enim. Kegiatan seperti ini sangat didukung oleh sang istri khususnya dan ketiga anaknya, sebagai penata rias dan busana, penari, dan management sanggar.

Rasyid pernah menjadi duta seni pada tahun 1993 pada pagelaran seni di TMII 
sebagi penari dan koreografer. Enam penata terbaik SUMSEL tahun 1996, garapan tari massal HARGANAS tingkat nasional di Kota Prabumulih sebagai koreografer, juara II parade tari SUMSEL dan juara II festival drama tari SUMSEL pata tahun 1997.

Keterlibatan Rasyid pada event-event seni tari mampu menghasilkan penghargaan pada setiap keikutsertaannya. Hal ini tidak menghentikan ia untuk terus berkarya, dan tidak menjadikan dirinya puas untuk berhenti menyalurkan hasrat berkesenian yang ia miliki, keberhasilan ini justru menjadi motivasinya untuk terus hidup dan berkembang diranah seni tari khususnya.

\section{c) Kegiatan Rasyid sebagai pimpinan sanggar Arizka Cipta}

\section{Managemen sanggar Arizka Cipta}

Proses manajemen sanggar Arizka Cipta di Kabupaten Muara Enim, tepatnya jalan Pembangunan No. 570 Pelita Sari pimpinan Rasyid tahap perencanaan awal dari kegiatan seni yang meraka tujukan direncanakan oleh manager sanggar Arizka Cipta,

yaitu Rasyid. Kemudian penggorgisasian dilakukan secara musyawarah, karena pengelolaan kelompok seni ini di naungi oleh anggota keluara Rasyid sendiri, mulai dari istrinya, keempat anaknya dan sanak saudara. Proses pengarahan pada tindak lanjut sebuah rencana kegiatan seni dilakukan oleh tetap kepada Bapak Rasyid selaku pimpinan sanggar, dan proses akhir yaitu pengendalian dilakukan bersama-sama, kerja sama pada prosese pengendalian sangatlah penting antara pimpinan sanggar, anggota sanggar dan manajemennya.

Sanggar Arizka cipta khusus dalam seni tari, hal ini dikarenakan latar belakang manager sebagai penari dan penata tari di Kabupaten Muara Enim, beliau memiliki motivasi yang besar untuk melestarikan seni tari hingga kegenerasi keluarganya. Seni menunjuk pada produksi atau kreasi manusia sebagai penggerak suatu managemen melalui beberapa jenis strategi untuk menghadapi seleksi alam dalam dunia bisnis. Jadi, seni berkaitan dengan seniman yang kreatif dan produk dari aktivitasnya, yakni karya seni yang memiliki eksistensi dan harga jual. Keindahan merujuk pada keunikan dan nilai keindahan hasil karya, estetika merujuk pada perasaan atau melihat objek yang memikat (Stolnitz, 1960: 21). 
Sanggar pimpinan Rasyid dipilih sebagai objek penelitian karena eksistensi sanggar tersebut dalam menghidupkan dan melestarikan kesenian di Kabupaten Muara Enim diayomi oleh pemerintah setempat. Banyaknya prestasi hingga ke tingkat Nasional menginspirasi untuk melihat bagaimana managemen sanggar tersebut sehingga sampai tahun 2013 namanya masih hidup dan eksis, bisa dikatakan eksis karena dalam satu minggu memiliki dua job untuk mengisi penyajian tari pada upacara pernikahan. Kemudian pada acara resmi, festival-festival sanggar Arizka Ciptalah yang mewakili Kabupaten dengan motto Bumi Serasan Sekundang yaitu seiya semufakat.

Selain itu, hal yang menarik dari komunitas seni tersebut adalah organisasi atau usaha keluarga. Pengelolah sanggar tersebut adalah anggota keluarga Rasyid sendiri. Sehingga hal ini boleh dikatakan sangat menguntungkan bagi pribadi khususnya dan keluarga.

\section{Target dan strategi sanggar Arizka Cipta}

Manager suatu kelompok seni dapat mengapresiasi karya seni hanya jika seseorang memiliki banyak pengalaman seni dan memahaminya secara estetik. Dengan latar belakang seorang penari dan penata tari di Kabupaten Muara Enim, manager sanggar tersebut memiliki strategi tersendiri, seni tari akan tetap hidup dan ditampilakan agar masyarakat bisa menikmati kesenian mereka walaupun nilai ekonomi dalam managemen keuangannya tidak memenuhi standar (wawancara Rasyid, 21 Juni 2013). Terdapat nilai estetik atau intrinsik seni yang terdapat dalam pikiran ketika seseorang berbicara tentang apresiasi seni, kritik seni, kepuasan batin si penikmat seni,artinya seorang manager harus memiliki kemampuan mendasar mengenai apa yang dikelolahnya.

Sangat baik jika ada pelatihan untuk mengembangkan kompetensi, tak hanya berkarya semata. Apalagi suatu kelompok seni atau sanggar yang wujud dari managemennya adalah pementasan harus pintar menyesuaikan selera masyarakat dan kebutuhan penikmat seni seiring perkembangan zaman. Seorang manager baiknya mengelolah anggota sanggar agar memiliki generasi kedepannya. Target sederhana yang menjadi visi sanggar Arizka adalah "seni tari di Kabupaten akan terus hidup dan berkembang dari generasi ke generasi".

Mengelola suatu managemen pertunjukan seni dengan era globalisasi saat ini harus memiliki kompeten agar mampu bersaing dalam hal kepuasan penikmat seni, jangan 
sampai seorang pengelola sanggar dengan kemajuan teknologi meninggalkan nilai tradisi dan bentuk baku sebuah seni. Hal ini tidak dilakukan oleh koreografer sanggar Arizka, yaitu Riski (putri ketiga dari Rasyid), beliau tetap menjaga bentuk baku sebuah tarian dalam menstrilisasi dan mendistorsi gerak. Gaya kontemporer hanya di garap agar bentuk tarian tidak statis, sehingga penikmat seni tidak bosan menyaksikan pertunjukan.

Pariwisata seringkali dipersepsikan sebagai mesin penggerak ekonomi atau penghasil devisa bagi pembangunan ekonomi di suatu Negara, tanpa terkecuali di Indonesia. Namun demikian pada kenyataannya, pariwisata memiliki spektrum fundamental pembangunan yang lebih luas bagi suatu negara.

Spillane (1993), pariwisata mestinya dikembangkan oleh setiap negara karena delapan alasan utama seperti berikut ini: (1)Pariwisata sebagai faktor pemicu bagi perkembangan ekonomi nasional maupun international. (2)Pemicu kemakmuran melalui perkembangan komunikasi, transportasi, akomodasi, jasa-jasa pelayanan lainnya. (3)Perhatian khusus terhadap pelestarian budaya, nilai-nilai sosial agar bernilai ekonomi. (4)Pemerataan kesejahtraan yang diakibatkan oleh adanya konsumsi wisatawan pada sebuah destinnasi. (5)Penghasil devisa. (6)Pemicu perdagangan international. (7)Pemicu pertumbuhan dan perkembangan lembaga pendidikan profesi pariwisata maupun lembaga yang khusus yang membentuk jiwa hospitality yang handal dan santun, dan (8)Pangsa pasar bagi produk lokal sehingga aneka-ragam produk terus berkembang, seiring dinamika sosial ekonomi pada daerah suatu destinasi.

\section{Managemen keuangan sanggar Arizka Cipta}

Hakekatnya uang adalah unsur pokok dalam managemen pertunjukan. Pengeluaran dan pemasukan harus diatur sedemikian rupa sehingga sasaran dapat dicapai sesuai tujuan dan keuangan stabil. Kualitas pertunjukan tetap baik walaupun mendominankan pengeluaran. Keuangan sanggar Arizka di bendaharai oleh istri manager itu sendiri, sehingga keterbukaan pemasukan dan pengeluaran termanagemen dengan baik.

Awal beridirinya sanggar Arizka hingga sampai saat ini tetap eksis diawali dengan modal pribadi, tekat untuk mendirikan sanggar agar ada lahan untuk mngelolah seni pertunjukan khususnya di Kabupaten Muara Enim membuat manager mendanai sanggar secara pribadi (usaha keluarga). Pemasukan setiap bulannya terkadang digunakan untuk 
keperluan pembuatan busana tari yang baru, kemudian pembelian alat musik, sehingga kebutuhan sanggar terpenuhi dari dana yang masuk hingga kedepannya akan menjadi modal kembali. "Para penari mendapat honor Rp. 60.000 setiap tarian, tidak ada perbedaan antara anak, keluarga dan anggota sanggar lainnya" ujar Rizki selaku penari inti pada setiap pertunjukan. Untuk honor ketika mengisi acara festival dan lainnya, honor disesuaikan dengan pemasukan, pemusik dan penari disamakan.

Hal yang menarikpun pada bidang tata rias dan penata busana, di sanggar tersebut penata rias dan busananya adalah putri ketiga dari manager sanggar bernama Atika. Untuk meningkatkan profesionalitas sebagai penata rias dan busana ia mengikuti kursus dalam waktu satu tahun di Johny Andrean kota Palembang. Walaupun ini usaha keluarga tetapi profesional tetap nomor satu.

Sejak kecil rizki sangat gemar menari hingga sekarang ia telah lulus sarjana pendidikan jurusan seni tari di Universitas PGRI Palembang, motivasi dari ayah selaku manager untuk menggali ilmu dibidang tari. Bisa dikatakan keluarga yang mendirikan sanggar tersebut adalah keluarga berdarah seni. Teori Genetik: di masa lalu banyak orang percaya bahwa seseorang dapat menjadi pemimpin karena darah atau keturunan.

\section{Sifat dan gaya kepemimpinan Rasyid}

Sifat Kepemimpinan yang diperlukan oleh seorang pemimpin dalam suatu organisasi harus memiliki kriteria-kriteria tertentu, dimana kriteria tersebut menurut George R. Terry (1992: 156) adalah penuh energi, memiliki stabilitas emosi, memeiliki pengetahuan tentang manusia, motivasi pribadi, kemahiran komunikasi, kecakapan, kecakapan sosial, kemampuan teknis. Sifat kepemimpinan manager sanggar Arizka menjadi tauladan khususnya bagi anggota keluarga dan anggota sanggar umumnya.

Motivasi selalu diberikan kepada anggota sanggar agar mereka semua berkarya dengan hati bukan hanya satu tujuan semata, seperti membuat suatu garapan tari bukan karna nilai jualnya tetapi krena unsur estetika yang ditonjolkan pada sajian tari. Kecakapan dan kemahiran Rasyid dalam memimpin sanggarnya membuat keberadaan sanggar tersebut banyak diminati oleh semua kalangan, dari SD hingga umum. Karena disini beliau tidak bersikap sebagai pemimpin yang menguasai segalanya tetapi lebih memposisikan dirinya pembina dan sebagai rekan kerja. 
Teori Perilaku sebagai berikut:

$\checkmark$ Pertama gaya otokratis yaitu pemimpin yang cenderung memusatkan wewenang, mendiktekan metode kerja, membuat keputusan unilateral, dan membatasi partisipasi karyawan

$\checkmark$ Kedua gaya demokratis yaitu pemimpin yang cenderung melibatkan karyawan dalam mengambil keputusan, mendelegasikan wewenang, mendorong partisipasi dalam memutuskan metode dan sasaran kerja, dan menggunakan umpan balik sebagai peluang untuk melatih karyawan.

$\checkmark$ Gaya Laissez-Faire, yaitu pemimpin yang umumnya memberi kelompok kebebasan penuh untuk membuat keputusan dan menyelesaikan pekerjaan dengan cara apa saja yang dianggap sesuai.

Melihat gaya kepemimpin menurut teori perilaku, gaya kepemimpinan Rasyid adalah gaya demokratis, sebagai kepala pimpinan sanggar dan kepala keluarga, beliau cenderung melibatkan anggota sanggar dalam mengambil keputusan, mendelegasikan wewenang, mendorong partisipasi dalam memutuskan metode dan tujuan dari kegiatan yang direncanakan, dan menggunakan umpan balik sebagai peluang untuk melatih anggota sanggarnya berkomunikasi dan bermusyawarah.

\section{Penyangga Sanggar Arizka}

Sanggar Arizka Cipta pimpinan Rasyit sebagai seniman tari di Kabupaten Muara Enim diayomi oleh Dinas Pariwisata Kabupaten Muara Enim. Berbagai kegiatan seni diberikan tanggung jawab untuk mewakili Kabupaten Muara Enimadalah sanggar Arizka Cipta. Hal ini menjadi nilai yang tinggi untuk kehidupan seni tari khususnya bagi daerah setempat. Berbagai prestasi dan karya-karyanya sehingga ia dipercaya untuk mengharumkan kesenian Muara Enim kedaerah lain, hingga tingkat Nasional.

Pariwisata seringkali dipersepsikan sebagai mesin penggerak ekonomi atau penghasil devisa bagi pembangunan ekonomi di suatu Negara, tanpa terkecuali di Indonesia. Namun demikian pada kenyataannya, setiap pariwisata memiliki spektrum fundamental pembangunan yang lebih luas bagi suatu negara. 


\section{d) Karya-karya Rasyid}

Pengalaman Rasyid dalam berkesenian memberikan banyak pengetahuan dibidang koreografer dan membuatnya menjadi seorang seniman yang ingin terus berkarya semasa hidupnya. Awal ia berkarya pada tahun 1985, ia menciptakan sebuah tari tradisi yaitu tari Ngibing yang meraih prestasi juara III pada festival tari se Sumatera Selatan dan juara IV pada festival Sriwijaya. Karya keduanya yaitu tari Gema Serasan yang telah ia ciptakan di tahun 1987 sebagai tari masal MTQ XVI sumatera selatan. Karya ketiga sebagai kebutuhan untuk malam penutupan PORSENI SUMSEL pada tahun 1988.

Tari Ibang Petang adalah karya Rasyid yang ke empat pada tahun 1990 dan meraih prestasi sebagai juara III Parade tari sumatera selatan pada tahun 1991. Pada tahun 1990 lahirlah tari Sembah dan meraih juara pertama pada festival tari di Kabupaten Muara Enim. Selanjutnya tahun 1992 Rasyid menciptakan karya tari Bebehas yang telah meraih prestasi juara III pada Parade tari SUMSEL yang ketika itu diselenggarakan tahun 1993. Sebagai hasil karyanya ia terpilih menjadi enam penata tari terbaik di Sumatera Selatan.

Tahun 1995 Rasyid, karyanya tari Bekarang sebagai garapan terbaik pada festival tari di Kabupaten Muara Enim. Ditahun yang sama Rasyid menciptakan kesenian Ngarak pada tari masal DUAJA Kabupaten Muara Enim. Untuk kebutuhan tari masal HARGANAS tingkat nasional di Kota Prabumulih Rasyid tampil dengan karyanya Pertemuan pada tahun 1996.

Tahun 1997, Rasyid meraih juara II Parade tari SUMSEL dengan karyanya Netau. Kemudian karya tari Netau juga meraih prestasi juara II festival drama tari. Karyanya yang sangat eksis saat ini adala tari Behuhung yang terakhir ditampilkan pada festival SRIWIJAYA tahun 2014 mendapat respon yang luar biasa dari penonton, karena unsur tradisi yang kental di dalam tarian itu membawa penonton merasa puas dengan pertunujukannya, tari Behuhung telah meraih prestasi juara pertama parade SUMSEL, parade tari tingkat nasional di TMII Jakarta. Tahun 1999 Rasyid meraih penghargaan sebagaikorografer terbaik dan penyaji unggulan 10 besar dengan karya Behuhung.

Tari Lentik adalah salah satu karya Rasyid yang meraih prestasi sebagai juara III di festival Sriwijaya tahun 2001, dan tampil pada malam REKOR Dewan Kesenian 
SUMSEL. Di tahun yang sama Rasyid menciptakan karya Elang Menarap yang telah meraih prestasi juara III di festival Sriwijaya tahun 2001. Pada event festival Sriwijaya Rasyid selalu diminta Pemerintah Setempat untuk mewakili Kabupaten Muara Enim, dan ia selalu menampilkan karya yang baru agar menambah variatif kesenian tradisi di Sumatera Selatan. Tahun 2003 karya Kinjau Ibungan meraih juara II di festival Sriwijaya tahun 2004.

Kumpay Beranyut merupakan salah satu karya Rasyid yang meraih prestasi juara pertama tingkat Provinsi Sumatera Selatan pada tahun 2008, dan sebagai wakil SUMSEL pada festival tari tradisional tingkat nasional. Tahun 2009 Rasyid meraih juara pertama pada festival Danau Ranau Sumatera Selatan dengan karyanya Gawi Ibungan. Tahun 2010 Rayid menciptakan suatu karya tari Setalan Seumah. Tari Kinjau Betuah pada tahun 2012 dalam Delagasi Seni Provinsi Sumatera Selatan di Taman Mini Indonesia Jakarta. Kemudian karyanya yang terakhir adalah tari Pengantin Nuju Mahligai tampil perdana pada acara pernikahan anak gubernur Kabupaten Muara Enim, dan tampil di Festival Sriwijaya tahun 2013. Dilihat dari periodesasi tahun ke tahun Rasyid selalu menciptakan sebuah karya tradisi yang kerap kali meraih prestasi, sikap disiplin dan rasa tanggung jawabnya sebagai seniman menuntut Rasyid untuk terus berkarya mengikuti jalannya waktu dengan etika dan estetika sebagai konsep garapannya.

\section{D.SIMPULAN}

Menjadi seorang koreografer menurut Rasyid sudah menjadi bagian dari kehidupan sehari-harinya, keinginan akan hal-hal yang indah merupakan hasrat hidup manusia yang pemenuhannya menunggu sampai hasratnya terpenuhi, memberikan ruang untuk selalu berpikir untuk selalu menciptakan hal baru, berimajinasi hingga terbentuk konsep garapan baru, dan mengapresiasikan semua yang ada di dalam kepala menjadi sebuah ide baru dan ide kreatif dalam berkarya. Rasyid adalah seseorang yang menyukai hal-hal yang baru tetapi ia juga sangat menghargai dan menjaga tradisi yang telah ada.

Rasyid beranggapan masa depan dan masa kini berawal dari masa lalu, ide kreatif, imajinasi ia dapatkan dari tradisi yang telah ada kemudian dijadikan sesuatu yang baru agar tradisi tetap diminati oleh masyarakat banyak dalam kemasan yang lebih menarik. 
Seorang koreografer yang handal adalah jika ia memiliki motivasi yang tinggi dalam menciptakan karya dan menghasilkan sebuah entitas yang unik, kaya, menarik dan dapat memberikan rangsangan-rangsangan kepada penikmat agar ikut berimajinasi dan sajian karya dalam kemasan yang menarik.

\section{DAFTAR PUSTAKA}

Andrianto, Tuhana Taufiq. Cara Cerdas Melejitkan IQ Kreatif Anak.Jogjakarta : Kata Hati, 2013.

Chandra, Julius. Kreativitas Bagaimana Menanam, Membangun, dan Mengembangkannya, Yogyakarta: Kanisius, 1994.

Gandadipura. Kreativitas, Jakarta: Dian Rakyat, 1983.

Hauser, Arnold. The Sociology of Art, Chicago and London, 1974.

Moleong, Lexy. Metode Penelitian Kualitatif, Bandung: Remaja Rosdakarya, 2014.

Munandar, Utami. Pengembangan Kreativitas Anak berbakat, Jakarta: Rineka Cipta, 2012.

Murgiyanto, Sal. Seni Menata Tari, Jakarta: Dewan Kesenian, 1983.

Rasyid. Deskripsi Tari Sembah Sebagai Tari Penyambut Tamu di Kabupaten Muara Enim Provinsi Sumatera Selatan, Muara Enim: Aksara Jaya, 2000.

Salim, Agus. Teori \& Paradigma Penelitian Sosial, Yogyakarta: Tiara Wacana, 2006.

Supriadi, Dedi. Kreativitas, Kebudayaan, dan Perkembangan Iptek, Jakarta: Alfabeta, 1977. 